\title{
Globular Region
}

National Cancer Institute

\section{Source}

National Cancer Institute. Globular Region. NCI Thesaurus. Code C14063.

A protein region consisting of a hydrophilic surface and a hydrophobic core. 